\title{
EVALUASI PENGELOLAAN LAYANAN TEKNOLOGI INFORMASI MENGGUNAKAN FRAMEWORK COBIT 5: STUDI KASUS PADA INSTITUT ILMU SOSIAL DAN ILMU POLITIK - IISIP YAPIS BIAK
}

\author{
Irwan \\ Program Studi Ilmu Komunikasi, Fakultas Ilmu Sosial dan Ilmu Politik \\ Institut Ilmu Sosial dan Ilmu Politik YAPIS Biak \\ Email : irwan@iyb.ac.id
}

\begin{abstract}
Abstrak
Pengelolaan layanan teknologi informasi menjadi penting agar pelaksanaan proses bisnis dapat berjalan dengan lancar. Evaluasi pengelolaan layanan tekonologi informasi perlu dilakukan untuk mengetahui kondisi sekarang yang dilakukan instansi atau perusahaan tersebut, sehingga dapat diambil langkah-langkah perbaikan proses bisnis selanjutnya. Institut Ilmu Sosial dan Ilmu Politik (IISIP) YAPIS Biak merupakan salah satu perguruan tinggi swasta yang tertua di Kabupaten Biak Numfor yang memerlukan dukungan teknologi informasi (TI) untuk menjalankan proses bisnisnya. Saat ini implementasi TI tidak berjalan dengan baik seperti yang diharapkan, beberapa permasalahan yang sering terjadi yaitu gangguan layanan TI yang berulang dengan permasalahan yang sama dan respon pengaduan layanan TI yang dianggap lambat karena proses pengaduan yang panjang. Penelitian ini bertujuan untuk mengetahui tingkat kapabilitas dari pengelolaan layanan TI pada IISIP YAPIS Biak serta memberikan rekomendasi aktifitas yang sesuai dengan kebutuhan institusi untuk meningkatkan kualitas pengelolaan layanan TI. Metode yang digunakan dalam mengukur tingkat kapabilitas mengacu pada COBIT 5 Process Assessment Model (PAM). Pengukuran tingkat kapabilitas pengelolaan layanan TI pada IISIP YAPIS Biak terdiri dua (2) proses yang dinilai yaitu DSSO2 (Manage Service Requests and Incidents) dan DSSO3 (Manage Problems). Hasil penelitian menunjukkan bahwa tingkat kapabilitas pengelolaan layanan TI berada pada tingkat/level 0 yaitu incomplete yang artinya bahwa proses ini tidak dilaksanakan atau gagal untuk mencapai tujuan prosesnya. Kegagalan utama hampir terjadi pada semua atribut baik pada base practices dan work products yang tidak memiliki aktifitas/kegiatan, aturan dan dokumentasi.
\end{abstract}

Kata kunci: Pengelolaan Layanan TI, COBIT 5, Tingkat Kapabilitas.

\begin{abstract}
The management of information technology service is important for the well running of business process. Evaluation of information technology service needs to be done to find out the current condition of the company as part of business process improvement. The Institute of Social and Political Sciences YAPIS Biak is one of the oldest private university in the district of Biak Numfor which needs information technology to do its business process. Currently, the information technology is not running as expected. Some problems occurred frequently and disruption of information technology services happens repeatedly with the similar problem and the complaint service response of information technology which is considered being slow due to the long complain process. The purpose of this research is to find out the capability of the information technology management process at the Institute of Social and Political Sciences YAPIS Biak and to give appropriate recommendation of activities for the institution in order to improve the management service quality of information technology. The used method is to
\end{abstract}


Jurnal "Gema Kampus" Edisi Vol.12 No.2 Tahun 2017

measure the IT capability level according to COBIT 5 Process Assessment Model (PAM). The capability level measurement of information technology service management at The Institute of Social and Political Sciences YAPIS Biak consists of two processes namely DSSO2 (Manage Service Requests and Incidents) and DSSO3 (Manage Problems). The results show that the capability level of information technology service management is at level 0 which means that it is not implemented yet or failed to achieve the purpose of the process. The failures occur in both base practice attributes and work products attributes where many of them do not have activity, rules, and documentation.

Keywords: Information Technology Service Management, COBIT 5, Level Capability.

\section{Latar Belakang}

Perkembangan teknologi informasi yang sudah semakin ketat khususnya dalam dunia lembaga pendidikan tinggi mendorong untuk memiliki langkah-langkah strategis baik faktor internal maupun faktor eksternal agar lembaga pendidikan tinggi tersebut sukses dan tetap bisa survive dalam segala bidang (Aswati, dkk., 2015). Pemanfaatan teknologi informasi (TI) pada lembaga pendidikan tinggi sangat dibutuhkan untuk memberikan kemudahan, meningkatkan efisiensi dan produktivitas bagi manajemen pendidikan. Untuk mencapai keberhasilan dalam pemanfaatan TI tersebut, harus dapat menerapkan tata kelola yang baik (Putra, dkk., 2015).

Pemanfaatan TI pada perguruan tinggi dapat dibagi menjadi tiga tingkatan, yaitu memberikan pelayanan dan dukungan administrasi, sebagai media pengajaran dan sarana komunikasi serta dapat membantu pengambilan keputusan (Setiawan, 2010). Wardani dan Puspitasari (2014) menjelaskan bahwa dalam dunia pendidikan, TI banyak dimanfaatkan sebagai sarana untuk menunjang proses pembelajaran, mempermudah dan membantu segala aktifitas yang memungkinkan, serta menyelaraskan peran TI dengan investasi yang telah dikeluarkan. Selain itu peran TI dalam pengambilan keputusan yang tepat sangat mempengaruhi efektifitas dan efisiensi dalam mencapai tujuan.
Andersen dan Danziger menjelaskan bahwa pada umumnya teknologi informasi memiliki pengaruh positif terutama yang berkaitan dengan peningkatan efisiensi dan efektivitas. Jika proses-proses yang ada dapat menjadi lebih efisien dan efektif, maka hal tersebut dapat meningkatkan kinerja. Penerapan tata kelola teknologi informasi pada perguruan tinggi sangat dibutuhkan agar terciptanya proses penyebaran ilmu dalam proses belajar mengajar yang lebih interaktif dan dinamis (Alberch dan Pirani, 2004). Maria, dkk (2012) menjelaskan bahwa penerapan TI dalam dunia perguruan tinggi yang tepat sasaran dapat meningkatkan kepuasan dan kemudahan dalam layanan bagi para stakeholder.

Control Objective for Information and related Technology (COBIT) dikembangkan oleh IT Governance Institute (ITGI) yang merupakan bagian dari Information Systems Audit and Control Association (ISACA) pada tahun 1996, hadir sebagai kerangka terkemuka yang diakui secara global untuk mencapai tata kelola TI yang efektif. Framework COBIT telah terbukti membantu untuk memenuhi beberapa kebutuhan manajemen dengan menjembatani kesenjangan antara risiko bisnis, kebutuhan kontrol, nilai perusahaan dan masalah teknis. Secara khusus, COBIT menyediakan model kematangan untuk menilai proses kemampuan organisasi, sehingga menajemen dapat mengetahui posisi/tingkatan 
Irwan "Evaluasi Pengelolaan Layanan Teknologi Informasi Menggunakan Framework COBIT 5: Studi Kasus pada Institut Ilmu Sosial dan Ilmu Politik - IISIP YAPIS Biak”

kematangan sekarang dan tingkatan yang diharapkan sesuai dengan standar internasional (Hardy, 2006). Pelaksanaan evaluasi tata kelola TI pada perguruan tinggi dapat menggunakan framework COBIT 5, karena di dalam framework COBIT 5 menyediakan penjabaran tata kelola TI perusahaan untuk menggambarkan peran utama dari informasi dan teknologi dalam menciptakan nilai perusahaan (Maria, dkk., 2012).

Pengelolaan layanan TI di IISIP YAPIS Biak saat ini dilakukan oleh Kepala Laboratorium Komputer dan Multimedia. Dari hasil pengamatan dan wawancara yang dilakukan dengan Kepala Laboratoium Komputer dan Multimedia (lampiran 1), diketahui bahwa pengelolaan layanan TI tidak berjalan dengan baik. Hal ini dapat dilihat pada beberapa permasalahan yang dihadapi oleh IISIP YAPIS Biak diantaranya adalah sarana dan prasarana layanan TI kurang dikelola dengan baik, kurangnya sumber daya manusia yang bekerja pada bagian TI, masih sering terjadinya pengaduan gangguan layanan TI yang langung ke teknisi tanpa melalui standar operasional prosedur (SOP) yang berlaku dan belum adanya call center untuk pengaduan layanan TI yang menyebabkan respon pengaduan menjadi lambat.

Permasalahan yang lainnya adalah masih sering terjadi adanya laporan ganguan layanan TI yang berulang dengan permasalahan yang sama, contohnya pada kejadian terkadang tidak dapat mengakses internet dan print server. Permasalahan yang berulang tersebut dapat menyulitkan teknisi/staf yang bertugas, laporan gangguan tersebut juga biasanya berupa gangguangangguan (incident) yang memerlukan penanganan yang cepat. Jika permasalahan ini tidak diselesaikan, maka akan membuat layanan TI menjadi tidak maksimal sehingga mengakibatkan kurangnya kenyamanan dan kepuasan layanan TI serta proses bisnis di IISIP YAPIS Biak dapat terganggu.

Hal ini juga sesuai dari tujuan rencana strategis IISIP YAPIS Biak dalam meningkatkan kualitas dan menyediakan layanan, sarana dan prasarana teknologi informasi untuk mendukung peningkatan mutu penyelenggaraan tridharma, maka dianggap perlu untuk mengevaluasi sejauhmana pengelolaan layanan teknologi informasi mendukung layanan proses-proses bisnis institusi ini dengan harapan, layanan yang berbasis TI dapat dikendalikan dan mendukung ketersediaan seluruh layanan proses bisnis pada IISIP YAPIS Biak. Tujuannya adalah memberikan kepastian layanan dalam memenuhi atau melebihi kebutuhan bisnis seluruh ketersediaan layanan yang diberikan IISIP YAPIS Biak, baik untuk saat ini atau yang akan datang.

Untuk melakukan pengukuran pengelolaan teknologi informasi terhadap layanan teknologi informasi pada IISIP YAPIS Biak, maka diperlukan sebuah metode atau framework yang dapat mengukurnya. Nuraeni dan Y. Bandung (2012) menjelaskan bahwa ada banyak metode yang dapat digunakan, yaitu Control Objective for Information and Related Technology (COBIT), The Committee of Sponsoring Organization of the Treadway Commission (COSO), Information Technology Infrastructure Library (ITIL) dan International Organization for Standardization ISO/IEC 17799.

Framework COBIT 5 menyediakan kerangka kerja yang komprehensif yang membantu organisasi dalam menciptakan nilai yang optimal dari TI dengan cara menjaga keseimbangan antara manfaat yang didapat dan mengoptimalkan tingkatan risiko serta penggunaan sumber daya untuk mencapai tujuan organisasi dalam tata kelola 
dan manajemen. COBIT 5 juga merupakan framework standar yang dapat digunakan untuk semua ukuran organisasi/perusahaan, baik yang komersial, non-for-profit atau di sektor publik (ISACA, 2012).

\section{Tinjauan Pustaka}

Penelitian tentang tata kelola teknologi informasi dengan menggunakan kerangka kerja (framework) COBIT telah banyak dilakukan oleh peneliti terdahulu. Penggunaan kerangka kerja COBIT dilakukan untuk melakukan evaluasi, perancangan tata kelola teknologi informasi secara keseluruhan atau fokus pada beberapa atau area tertentu. Penelitian tersebut antara lain dilakukan oleh Satria (2010) yang menggunakan COBIT 4.1 untuk mengetahui tingkat kematangann UGM Goes Open Sources (UGOS) dan kepuasan pengguna

Hasil dari penelitian menunjukkan bahwa dari persepsi pengelola UGOS, nilai-nilai kematangan pada pengelola UGOS belum dapat menjamin kepuasan pengguna UGOS. Disisi lain, pengguna juga masih terasa kurang puas dengan kenyataan sistem layanan UGOS yang ada. Tingkat kepuasan ini dipicu oleh kenyataan bahwa kinerja dari layanan sistem UGOS hanya dapat memenuhi kurang lebih $79.35 \%$ dari harapan pengguna.

Penelitian oleh Purwanto (2010) menjelaskan tentang evaluasi tata kelola TI menggunakan kerangka kerja COBIT dalam mendukung layanan sistem informasi akademik (SIAKAD), studi kasus pada Universitas Budi Luhur. Penelitian ini menggunakan kerangka kerja COBIT 4.0 dengan fokus pada domain Deliver and Support (DS) dan Monitor and Evaluated (ME).

Hasil tingkat kematangan saat ini lebih kecil daripada tingkat kematangan yang diharapkan yaitu diarahkan pada menuju tingkat kematangan 3-defined process.
Jurnal "Gema Kampus" Edisi Vol.12 No.2 Tahun 2017 Penelitian yang dilakukan oleh Adikara (2013) menjelaskan tentang implementasi tata kelola TI perguruan tinggi berdasarkan COBIT 5 pada laboratorium rekayasa pengkat lunak (RPL) Universitas Esa Unggul. Penelitian ini hanya fokus pada domain Evaluate, Direct and Monitoring (EDM) proses 4 atau EDM04 dengan tujuan mendapatkan hasil implementasi kerangka kerja COBIT 5, memberikan langkahlangkah untuk meningkatkan kinerja serta rekomendasi perencanaan tata kelola LabRPL di masa yang akan datang.

Penelitian tentang evaluasi penerapan TI di Perguruan Tinggi Swasta (PTS) Yogyakarta oleh Setiawan (2008) dalam penelitiannya menggunakan kerangka kerja COBIT 4.1, mengungkapkan hasil evaluasi dari penelitian yang menggunakan 50 sampel perguruan tinggi swasta di Yogyakarta sebagian besar sudah cukup baik yaitu diatas skala 3 (defined). Berdasarkan hasil evaluasi, maka perguruan tinggi swasta di Yogyakarta dapat dibagi dalam 3 kelompok tingkat kematangan (maturity) TI, yaitu tingkat kematangan rendah sebanyak 5 PTS, tingkat kematangan sedang sebanyak 38 PTS dan tingkat kematangan tinggi sebanyak 7 PTS.

Penelitian oleh Robeiro dan Gomes (2009) meniliti tata kelola TI dengan penerapan kerangka kerja COBIT pada institusi perguruan tinggi di Portugal (studi kasus). COBIT memastikan persyaratan untuk sertifikasi kualitas layanan dan pengelolaan serta pengendalian sistem informasi (SI) dan TI. Hasil penelitian tersebut adalah bahwa dengan penerapan kerangka kerja COBIT di lembaga institusi perguruan tinggi dapat meningkatkan kualitas layanan, SI dapat dikendalikan dan dikelola lebih efisien.

Berdasarkan hasil tinjauan pustaka dari beberapa penelitian terdahulu, penulis menarik kesimpulan bahwa framework COBIT merupakan model yang dapat 
Irwan "Evaluasi Pengelolaan Layanan Teknologi Informasi Menggunakan Framework COBIT 5: Studi Kasus pada Institut Ilmu Sosial dan Ilmu Politik - IISIP YAPIS Biak”

diterapkan untuk mengevaluasi tata kelola maupun manajemen teknologi informasi pada perguruan tinggi yang menerapkan TI dalam menunjang seluruh kegiatan proses bisnisnya. Penulis juga menyimpulkan bahwa framework COBIT 5 lebih tepat diterapkan karena lebih berorientasi pada prinsip dibandingkan pada proses dimana penggunaan prinsip-prinsip lebih mudah dipahami dan diterapkan dalam konteks enterprise secara lebih efektif. Selain itu COBIT sebelumnya belum dapat menangani pandangan yang komprehensif dari semua risiko-risiko dan asumsi operasional dalam menyelaraskan TI dan bisnis yang terkait dengan penggunaan TI.

\section{Teori Dasar}

\section{Tata Kelola Teknologi Informasi}

Weill dan Ross (2004) mendefinisikan tata kelola TI adalah "Specifying the decision right and accountability framework to encourage desirable behavior in using IT". Maksud pengertian tersebut adalah bahwa tata kelola TI merupakan kerangka kerja yang spesifik dalam pengambilan keputusan dan akuntabilitas untuk mendukung kebiasaan perusahaan dalam menggunakan TI.

Jogiyanto dan Abdillah (2011) mendefinisikan tata kelola TI sebagai suatu struktur dan proses pengambilan keputusan TI di tingkat korporat untuk mengarahkan perilaku yang dinginkan dari insan TI dan memastikan keberhasil-keberhasilan TI dalam rangka penciptaan nilai bagi para stakeholder.

\section{COBIT (Control Objectives of Information and related Technology) \\ COBIT dikembangkan oleh IT} Governance Institute (ITGI) yang merupakan bagian dari Information System Audit and Control Association (ISACA). COBIT merupakan sekumpulan dokumentasi dan panduan untuk mengimplementasi Tata kelola TI, kerangka kerja yang komprehensif yang membantu organisasi/perusahaan dalam menciptakan nilai yang optimal dari TI dengan cara menjaga keseimbangan antara manfaat yang didapat dan mengoptimalkan tingkatan risiko serta penggunaan sumber daya untuk mencapai tujuan organisasi dalam tata kelola dan manajemen.

\section{Model Referensi Proses COBIT 5}

Dalam COBIT 5 sudah terdapat model referensi proses yang mendefinisikan dan menjelaskan secara detail beberapa proses tata kelola dan manajemen. Setiap perusahaan harus menentukan rangkaian prosesnya sendiri sesuai dengan situasinya yang spesifik (ISACA, 2012). Model referensi proses pada Gambar 1 merupakan model referensi proses COBIT yang telah diintegrasikan dengan model proses Risk IT dan Val IT. 


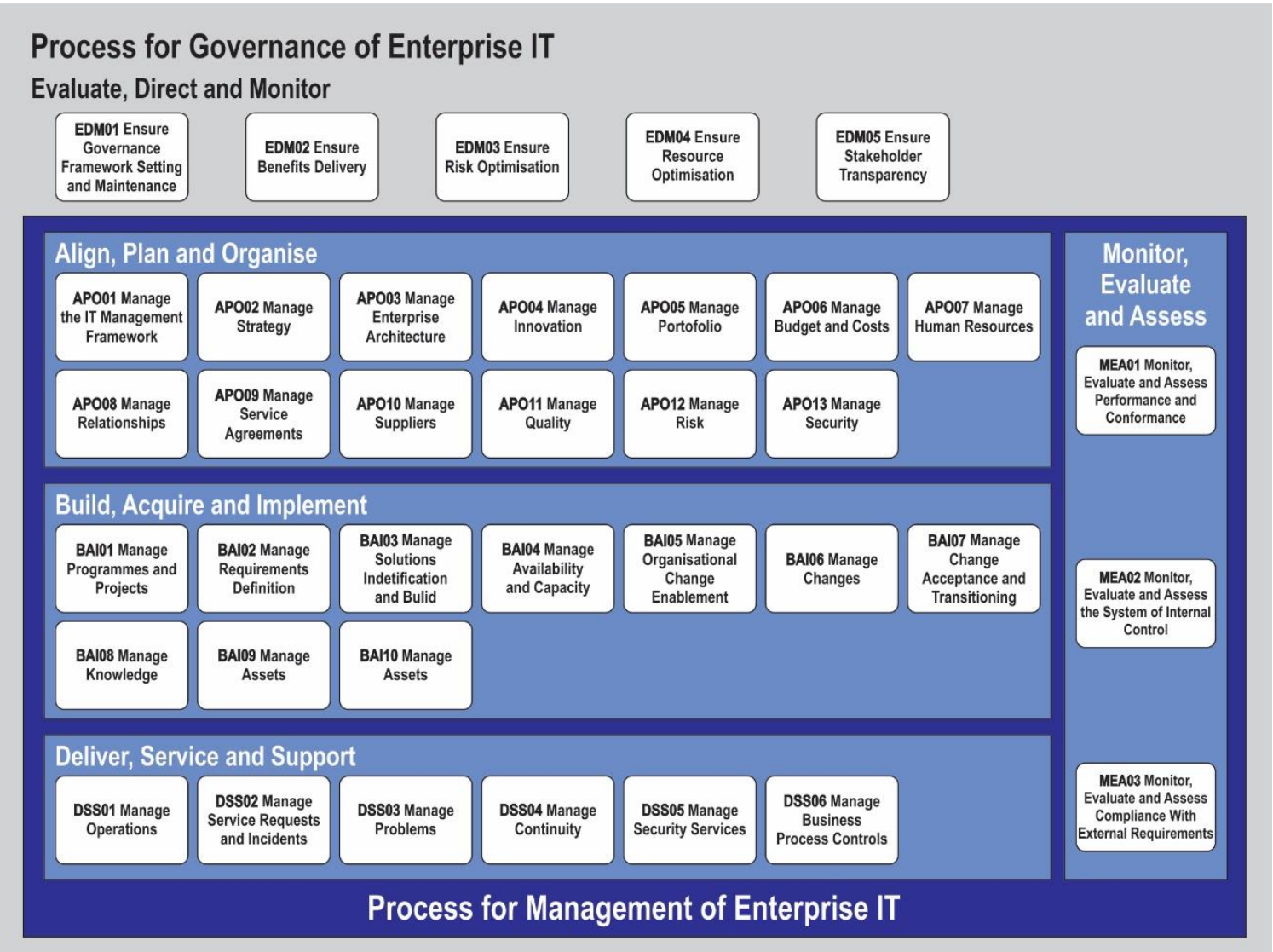

Gambar 1 Model referensi proses (ISACA, 2012).

Gambar 1 menjelaskan model referensi proses yang terbagi dalam dua jenis area yaitu governance process dan management process dari Enterprise IT dengan total proses sebanyak 37 proses.

\section{Process for Governance of Enterprise IT (GEIT)}

Area ini memiliki satu (1) domain yaitu domain Evaluate, Direct and Monitor (EDM) yang terdiri dari 5 proses. EDM adalah proses tata kelola yang berhubungan dengan tata pemangku kepentingan (stakeholder).

2. Process for Management of Enterprise IT (MEIT)

Area ini memiliki empat (4) domain yaitu Align, Plan and Organise (APO), Build, Acquire and Implement (BAI), Deliver, Service and Support (DSS) dan Monitor, Evaluate and Assess (MEA) yang semua terdiri 32 Proses.

\section{Model Kapabilitas Proses COBIT 5}

COBIT 5 menyediakan model pengukuran untuk mengetahui kapabilitas dari proses yang telah dijalankan. Metode yang digunakan adalah Process Assessment Model (PAM) yag sesuai dengan ISO/IEC 15504, standar mengenai software engineering dan proses assessment. Metode PAM dinilai lebih konsisten, objektif tidak memihak (impartial) dan proses penilaian berulang (repeatable) sehingga dapat mempresentasikan proses yang diukur dibandingkan dengan metode lain (Noorhasanah, dkk. 2015). Model kapabilitas proses pada COBIT 5 digunakan untuk mengukur performansi pada setiap proses atributnya.

Tingkatan kapabilitas setiap proses yang dinilai dinyatakan dengan tingkatan kapabilitas dari 0 sampai 5, sebagaimana yang dijelaskan pada Tabel 1 (ISACA, 2012). 
Irwan "Evaluasi Pengelolaan Layanan Teknologi Informasi Menggunakan Framework COBIT 5: Studi Kasus pada Institut Ilmu Sosial dan Ilmu Politik - IISIP YAPIS Biak”

Tabel 1 Tingkatan Proses Kapabilitas

\begin{tabular}{|l|l|}
\hline $\begin{array}{l}\text { Tingkatan } \\
\text { Proses }\end{array}$ & Kapabilitas \\
\hline 0 (Incomplete) & $\begin{array}{l}\text { Proses ini tidak dilaksanakan } \\
\text { atau gagal untuk mencapai } \\
\text { tujuan prosesnya. Hanya ada } \\
\text { sedikit atau tidak ada bukti } \\
\text { pencapaian secara sistematis } \\
\text { dari setiap tujuan proses }\end{array}$ \\
\hline 1 (Performed) & $\begin{array}{l}\text { Proses yang } \\
\text { diimplementasikan berhasil } \\
\text { mencapai tujuannya. }\end{array}$ \\
\hline 2 (Managed) & $\begin{array}{l}\text { Proses yang sudah dijalankan } \\
\text { selanjutnya diimplementasi } \\
\text { dengan cara yang lebih teratur } \\
\text { (direncanakan, dipantau dan } \\
\text { disesuaikan) dan produk yang } \\
\text { dihasilkan telah ditetapkan, } \\
\text { dikendalikan dan dijaga } \\
\text { dengan baik. }\end{array}$ \\
\hline 3 (Established) & $\begin{array}{l}\text { Proses yang telah dikelola } \\
\text { selanjutnya diimplementasi } \\
\text { menggunakan proses tertentu } \\
\text { yang telah ditetapkan, yang } \\
\text { mampu mencapai outcome } \\
\text { yang diharapkan. }\end{array}$ \\
\hline 5 (Optimizing) & $\begin{array}{l}\text { Proses yang telah ditetapkan } \\
\text { sekarang beroperasi di dalam } \\
\text { batasan yang telah ditentukan } \\
\text { untuk mencapai outcome } \\
\text { proses yang diharapkan. } \\
\text { selanjutnya ditang telah di prediksi } \\
\text { secara berkelanjutan untuk } \\
\text { memenuhi relevansi tujuan } \\
\text { bisnis saat ini. }\end{array}$ \\
\hline
\end{tabular}

\section{Model Proses Penilaian COBIT 5}

Model proses penilaian COBIT 5 didasarkan pada proses penilaian standar internasional ISO/IEC 15504 yang dirancang untuk perusahaan/organisai dengan metodologi yang handal, kuat dan berulang dengan tujuan sebagai dasar untuk menilai kemampuan proses TI perusahaan/organisasi (ISACA, 2012).
Proses kapabilitas pada tingkat 0 tidak memiliki atribut. Tingkatan 0 mencerminkan proses tidak diterapkan atau proses yang gagal untuk mencapai tujuannya.Tingkatan kapabilitas suatu proses diukur berdasarkan penilaian terhadap sembilan proses atribut (diawalai dengan PA) pada tiap-tiap tingkat yang dijelaskan dalam ISO/IEC 15504 seperti yang ditunjukkan pada Gambar 2

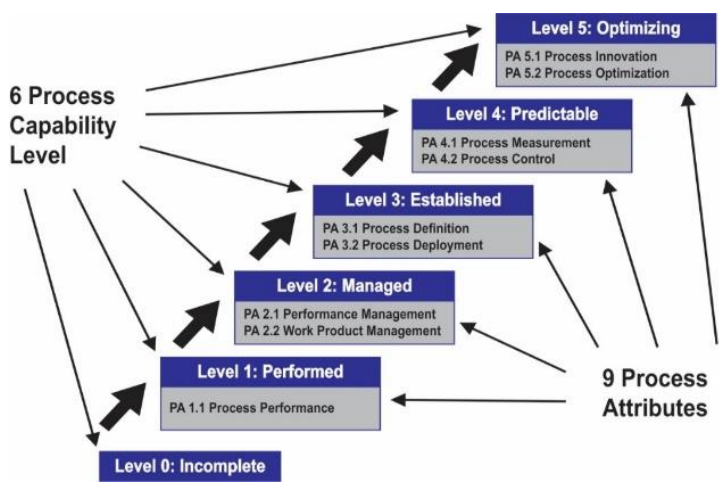

Gambar 2 Proses atribut dalam tingkatan proses kapabilitas (ISACA, 2012).

Setiap tingkat kapabilitas hanya akan dicapai jika tingkat sebelumnya telah sepenuhnya tercapai (fully achieved). Skala yang digunakan untuk menilai tingkat kapabilitas menggunakan skala peringkat ISO/IEC 15504-2. Persentase peringkat ini dijelaskan pada Tabel 2 di bawah ini.

Tabel 2 Persentase Peringkat

\begin{tabular}{|c|l|l|}
\hline Abbreviation & Description & \%Achieved \\
\hline N & $\begin{array}{l}\text { Not } \\
\text { achieved }\end{array}$ & $\begin{array}{l}\text { O to 15\% } \\
\text { achievement }\end{array}$ \\
\hline P & $\begin{array}{l}\text { Partially } \\
\text { achieved }\end{array}$ & $\begin{array}{l}>15 \% \text { to } \\
50 \% \\
\text { achievement }\end{array}$ \\
\hline L & $\begin{array}{l}\text { Largely } \\
\text { achieved }\end{array}$ & $\begin{array}{l}>50 \% \text { to } \\
85 \% \\
\text { achievement }\end{array}$ \\
\hline F & $\begin{array}{l}>85 \% \text { to } \\
\text { Fully } \\
\text { achieved } \\
\text { achievement }\end{array}$ \\
\hline
\end{tabular}




\section{Fokus Area Pengelolan Layanan TI}

Pemilihan domain proses dalam proses evaluasi pengelolaan layanan TI ini berdasarkan hasil pra-penelitian berupa observasi dan wawancara yang telah dijelaskan pada latar belakang masalah. Dari beberapa permasalahan yang ada pada IISIP YAPIS Biak, maka permasalahan dibawah ini merupakan permasalahan yang sering terjadi pada aspek pengelolaan layanan TI. Adapun relevansi permasalahan yang dipilih berdasarkan pemetaan dengan framework COBIT 5 ditunjukkan pada Tabel 3 berikut:

Tabel 3 Relevansi Permasalahan Terhadap Proses COBIT 5

\begin{tabular}{|c|l|l|l|}
\hline No & Permasalahan & \multicolumn{2}{l|}{ Proses COBIT 5 } \\
\hline 1. & $\begin{array}{l}\text { Respon } \\
\text { pengaduan } \\
\text { layanan TI yang } \\
\text { masih lambat, } \\
\text { dikarenakan } \\
\text { proses } \\
\text { pengaduan yang } \\
\text { masih panjang. }\end{array}$ & DSS02 & $\begin{array}{l}\text { Manage } \\
\text { Service } \\
\text { Request and } \\
\text { Incident / } \\
\text { Mengelola } \\
\text { Permintaan } \\
\text { 2. }\end{array}$ \\
& $\begin{array}{l}\text { Sering terjadi } \\
\text { adanya ganguan TI } \\
\text { layanan TI yang } \\
\text { berulang } \\
\text { dengan } \\
\text { permasalahan } \\
\text { yang sama }\end{array}$ & DSS03 & $\begin{array}{l}\text { Manage } \\
\text { Problems / } \\
\text { Mengelola } \\
\text { Masalah TI }\end{array}$ \\
\hline 3. & $\begin{array}{l}\text { Belum adanya } \\
\text { ketersediaan } \\
\text { SOP untuk } \\
\text { mekanisme } \\
\text { penanganan } \\
\text { masalah }\end{array}$ & DSS03 & $\begin{array}{l}\text { Manage } \\
\text { Problems / } \\
\text { Mengelola } \\
\text { Masalah TI }\end{array}$ \\
\hline
\end{tabular}

Berdasarkan relevansi permasalahan yang terjadi pada IISIP YAPIS Biak, maka penulis fokus pada area proses DSS02 (Manage Service Request and Incident) dan DSS03 (Manage Problems).

Jurnal "Gema Kampus" Edisi Vol.12 No.2 Tahun 2017

\section{Metode Penelitian}

Metode penelitian merupakan proses atau cara ilmiah yang dilakukan secara sistematis untuk mendapatkan data yang akan digunakan untuk keperluan penelitian (Sugiyono, 2012). Metode yang digunakan dalam penelitian ini menggunakan pendekatan kualitatif yang menekankan pada aspek pemahaman dan pengamatan partisipatif. Sedangkan jenis penelitian yang digunakan adalah jenis deksriptif dengan tujuan mendeskripsikan suatu keadaan atau kondisi yang dilakukan pada saat ini atau dalam kurun waktu yang singkat (Guritno, dkk., 2010).

Metodologi penelitian ini menggunakan metode pengumpulan data dengan cara observasi, wawancara, studi pustaka dan kuesioner. Sedangkan untuk metode analisis data mengacu pada COBIT 5 assessment process activities yang dapat dibagi menjadi tiga bagian yaitu: pertama, Assessment Process Planning (Initiation, Planning the assessment dan Briefing); kedua, Assessment Process Assessing (Data collection, Data analysis dan Process attribute rating) dan ketiga Assessment Process - Reporting (Reporting the results) untuk mendapatkan tingkat kapabilitas pada masing-masing proses sehingga dapat melakukan penyusunan rekomendasi untuk perbaikan proses yang berkelanjutan.

\section{Hasil dan Pembahasan}

Hasil dan pembahasan evaluasi pengelolaan layanan TI pada IISIP YAPIS Biak disusun berdasarkan alur penelitian dalam metodologi penelitian yang mengacu pada COBIT 5 Assessment Process Activities.

\section{Initiation}

Tahap ini bertujuan untuk menjelaskan hasil identifikasi dari beberapa informasi yang dikumpulkan. Beberapa kegiatan yang telah dilakukan untuk mendapatkan 
Irwan "Evaluasi Pengelolaan Layanan Teknologi Informasi Menggunakan Framework COBIT 5: Studi Kasus pada Institut Ilmu Sosial dan Ilmu Politik - IISIP YAPIS Biak"

informasi yang berkaitan dengan penelitian yaitu melakukan observasi awal, wawancara dan studi pustaka. Observasi awal dilakukan dengan mengamati langsung dan mempelajari pengelolaan layanan TI pada IISIP YAPIS Biak. Sedangkan wawancara dilakukan dengan cara melakukan komunikasi secara langsung dengan pihakpihak/aparat yang bertanggungjawab terhadap TI dengan cara mengajukan beberapa pertanyaan untuk memperoleh yang dibutuhkan yang berhubungan dengan TI.

\section{Planning the Assessment}

Setelah dilakukan analisa dalam initiation maka didapatkan ruang lingkup proses yang akan dievaluasi, adapun proses yang dipilih dan dievaluasi yaitu pada proses domain DSS02 (Manage Service Requests and Incidents) dan DSS03 (Manage Problems). Selanjutnya dibuatkan kuesioner pada masing-masing proses. Responden yang mengisi kuesioner dipilih menggunakan teknik purposive sampling. Responden tersebut disesuaikan menggunakan diagram Responsible, Accountable, Consulted and/or Informed (RACI) dari COBIT 5 yang telah dipetakkan kedalam stuktur organisasi IISIP YAPIS Biak khususnya pada proses DSS02 dan proses DSS03.

\section{Briefing}

Pada tahap ini, dilakukan penjadwalan penelitian dan pengarahan kepada responden penilai pengelolaan layanan TI pada IISIP YAPIS Biak sehingga memahami masukan, proses dan keluaran yang akan dinilai pada proses DSS02 Manage Service Request and Incident dan proses DSS03 Manage Problems.

\section{Data Collection}

Kegiatan yang dilakukan pada tahap ini yaitu mengumpulkan seluruh data hasil temuan yang berhubungan dengan penelitian baik berupa data-data kampus, hasil wawancara dan kuesioner sehingga dapat memberikan informasi dalam aktifitas proses evaluasi pengelolaan layanan TI pada IISIP YAPIS Biak yang telah dilakukan

\section{Data Analysis}

Pada tahap ini pengolahan data dilakukan dengan analisis data terhadap kuesioner yang telah dijawab oleh responden yang kemudian diproses menggunakan metode perhitungan Guttman

\section{a. Proses DSS02 Manage Service Request and Incidents}

Secara keseluruhan hasil pengukuran level 1 process performance dengan perhitungan rata-rata base practices dan work products maka didapat rata-ratanya adalah 25\% yang berada pada tingkat rating scale $\mathrm{P}$ (Partially Achieved). Pada proses ini kegagalan utama hampir terjadi pada semua atribut work product karena tidak didukung dengan dokumen berupa sk/perturan untuk permintaan layanan TI dan insiden yang ada. Pengukuran tidak dapat dilanjutkan ke level 2, karena untuk dapat dilakukan pengukuran ke level berikutnya skala harus menunjukkan rating scale F (Fully Achieved). Selanjutnya hasil pencapaian proses DSS02 tersebut dimasukkan kedalam template tingkat kapabilitas, seperti yang ditunjukkan pada Tabel 4 berikut.

\section{b. Proses DSS03 Manage Problems}

Secara keseluruhan hasil pengukuran level 1 process performance pada proses DSS03 dengan perhitungan rata-rata base practices dan work products maka didapat rata-ratanya adalah $7 \%$ yang berada pada tingkat rating scale $\mathrm{N}$ (Not Achieved). Proses pada level ini dianggap 
Jurnal "Gema Kampus" Edisi Vol.12 No.2 Tahun 2017

gagal karena process performance $<15 \%, \quad$ Tabel 5 Hasil Pencapaian Tingkat

hal ini mengindikasikan bahwa proses Kapabilitas Proses DSS03

tidak terlaksana. Pada

proses ini kegagalan

utama hampir terjadi

pada semua atribut

baik pada base

practices dan work

products yang tidak

memiliki

aktifitas/kegiatan,

aturan, pencatatan/

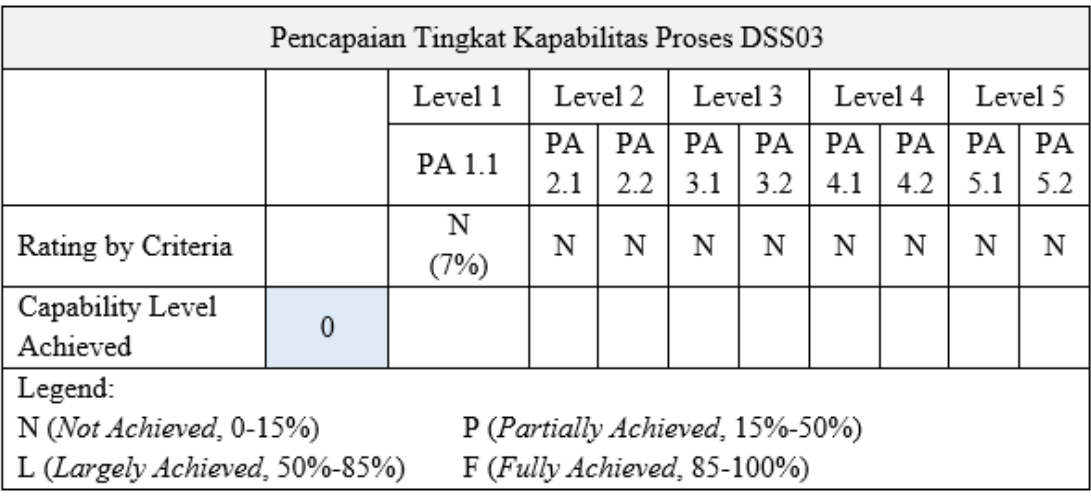

dokumentasi dan komunikasi mengenai masalah TI.

\section{Process Attribute Rating}

Selanjutnya hasil pencapaian proses DSS02 dan DSS03 tersebut dimasukkan kedalam template tingkat kapabilitas, seperti yang ditunjukkan pada Tabel 4 dan Tabel 5 berikut.

Tabel 5 menjelaskan bahwa pencapaian tingkat kapabilitas untuk proses DSS03 Manage Problems berada pada level 0 (Incomplete) yang berarti proses tidak dilaksanakan atau gagal untuk mencapai tujuan prosesnya. Hanya ada sedikit atau tidak ada bukti pencapaian secara sistematis dari setiap tujuan proses.

\section{Reporting the Results}

Tabel 4 Hasil Pencapaian Tingkat

Setelah menentukan process attribute Kapabilitas Proses DSS02

rating pada masing-masing proses yang

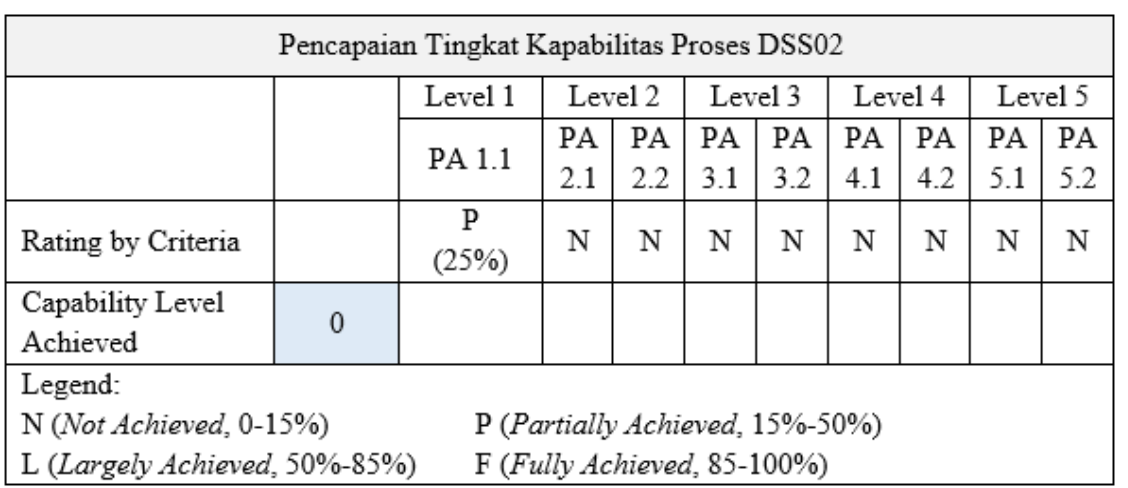

dinilai, maka tahap selanjutnya adalah merangkum hasil pencapaian tingkat kapabilitas untuk semua proses dan membuat rekomendasi dari hasil pencapaian tingkat kapabilitas tersebut.

Tabel 4 menjelaskan bahwa pencapaian tingkat kapabilitas untuk proses DSS02 Manage Service Request and Incidents berada pada level 0 (Incomplete) yang berarti proses tidak dilaksanakan atau gagal untuk mencapai tujuan prosesnya. Hanya ada sedikit atau tidak ada bukti pencapaian secara sistematis dari setiap tujuan proses.

kapabilitas untuk semua proses dapat dilihat pada Tabel 6 berikut.

\begin{tabular}{|c|c|c|c|c|c|c|c|}
\hline \multirow{2}{*}{ No } & \multirow{2}{*}{ Proses COBIT yang dinilai } & \multicolumn{6}{|c|}{ Level Kapabilitas } \\
\hline & & $\mathbf{0}$ & 1 & 2 & 3 & 4 & 5 \\
\hline 1. & $\begin{array}{l}\text { DSS02 Manage Service and } \\
\text { Request and Incidents }\end{array}$ & $\begin{array}{c}0 \\
(25 \%)\end{array}$ & & & & & \\
\hline 2. & DSS03 Manage Problems & $\begin{array}{c}0 \\
(7 \%)\end{array}$ & & & & & \\
\hline
\end{tabular}

Tabel 6 Hasil Pencapaian Tingkat

Kapabilitas Semua Proses 
Irwan "Evaluasi Pengelolaan Layanan Teknologi Informasi Menggunakan Framework COBIT 5:

Studi Kasus pada Institut Ilmu Sosial dan Ilmu Politik - IISIP YAPIS Biak”"

\begin{abstract}
Hasil penilaian tingkat kapabilitas berdasarkan kerangka kerja COBIT 5 pada Tabel 6 menujukkan pengelolaan layanan TI di IISIP YAPIS Biak yang belum efektif dan memberikan gambaran peluang perbaikan dalam beberapa proses. Peluang perbaikan ini selanjutnya digunakan sebagai rekomendasi perbaikan pengelolaan layanan TI di IISIP YAPIS Biak yang lebih baik.
\end{abstract}

Penyusunan rekomendasi ini didasarkan pada kegiatan observasi awal, aktifitasaktifitas base practices dan dokumentasi work products yang minimal harus dimiliki setiap proses. Berikut merupakan rekomendasi yang diberikan untuk setiap proses.

\section{a. Rekomendasi Mengelola Permintaan Layanan TI dan Insiden (DSS02)}

1) Mendefinisikan model dan skema klasifikasi permintaan layanan TI dan insiden.

2) Melakukan sosialisasi SOP pengelolaan layanan TI kepada seluruh staf.

3) Mengidentifikasi, merekam, mengklasifikasikan dan memprioritaskan permintaan layanan TI dan insiden yang didasarkan pada layanan Service Level Agreement (SLA) serta menetapkan peran dan tanggung jawab.

4) Melakukan verifikasi, menyetujui dan memenuhi permintaan layanan dengan memilih prosedur permintaan yang tepat dan memverifikasi bahwa permintaan layanan TI memenuhi kriteria permintaan yang telah didefinisikan.

5) Melakukan identifikasi dan mencatat seluruh gejala insiden serta menentukan kemungkinan penyebab masalah untuk penyelesaiannya.
6) Melakukan

pencatatan/mendokumentasi yang teridentifikasi masalah serta melakukan tindakan perbaikan untuk memulihkan layanan terkait TI.

7) Melakukan verifikasi kepuasan permintaan layanan TI dan/atau kepuasan pemecahan insiden dan penyelesaiannya.

8) Melakukan pelacakan secara rutin dengan menganilisis dan melaporkan permintaan layanan dan insiden TI untuk memberikan informasi guna perbaikan berkelanjutan.

9) Membuat/pengadaan aplikasi yang dapat menampung seluruh aktifitas dalam permintaan layanan TI dan insiden, sehingga dapat memberikan informasi secara cepat dan tepat dalam penanganan masalah dan penyelesaiannnya serta dapat digunakan sebagai database pengetahuan.

10) Menyediakan nomor call center untuk pengaduan layanan TI

b. Rekomendasi Mengelola Masalah TI (DSS03)

1) Membuat skema klasifikasi masalah TI

2) Mendefinisikan dan menerapkan prosedur dan kriteria untuk laporan masalah yang teridentifikasi masalah agar proses perbaikan dan pembaharuan dilakukan berdasarkan urutan prioritas.

3) Menganalisis dan mendiagnosa masalah TI dengan membuat fungsi troubleshooter untuk dapat mengetahui problem yang terjadi secara cepat dan tepat sasaran.

4) Melakukan dokumentasi terhadap catatan error yang diketahui dan menentukan pemecahan masalah 
Jurnal "Gema Kampus" Edisi Vol.12 No.2 Tahun 2017

yang tepat dari akar permasalahan yang telah dianalisis.

5) Mengidentifikasi dan memulai dengan solusi berkelanjutan menangani akar penyebab masalah, sehingga personel yang melakukan tindakan dapat membuat rencana pengembangan untuk mencegah insiden yang dapat terjadi dikemudian hari.

6) Membuat laporan secara berkala yang berisi monitoring solusi masalah.

\section{Kesimpulan dan Saran}

Beberapa kesimpulan dari penelitian yang telah dilakukan dan juga terdapat beberapa saran yang diberikan untuk pengembangan lebih lanjut terkait permasalahan pada pengelolaan layanan TI

\section{Kesimpulan}

Berdasarkan hasil evaluasi pengelolaan layanan TI pada IISIP YAPIS Biak yang dilakukan, diperoleh kesimpulan sebagai berikut:

a. Tingkat kapabilitas proses-proses pengelolaan layanan TI yang relevan dengan permasalahan di lingkungan IISIP YAPIS Biak semuanya masih berada pada level 0 (incomplete), yang berarti bahwa proses ini tidak dilaksanakan atau gagal untuk mencapai tujuan prosesnya. Hanya ada sedikit atau tidak ada bukti pencapaian secara sistematis dari setiap tujuan proses.

b. Hasil pengukuran yang dilakukan terhadap dua proses yang dipilih menunjukkan bahwa IISIP YAPIS Biak belum menerapkan langkah-langkah aktifitas base practice dan tidak adanya dokumen work product yang mencerminkan bahwa pengelolaan layanan TI belum efektif. c. Untuk dapat meningkatkan kualitas pengelolaan layanan TI, maka diberikan beberapa rekomendasi aktifitas yang disesuaikan juga dengan base practice pada COBIT 5.

\section{Saran}

Berikut merupakan saran yang diberikan oleh penulis adalah sebagai berikut:

a. Penelitian yang dilakukan hanya pada dua proses, sehingga disarankan kepada penelitian selanjutnya untuk melakukan penilaian tingkat kapabilitas dengan menggunakan proses area lain yang disesuaikan dengan permasalahan yang terjadi pada IISIP YAPIS Biak

b. Segera membuat/pengadaan aplikasi pengaduan layanan TI yang dapat menampung seluruh aktifitas permintaan layanan TI dan insiden seta cara penanganan masalah dan penyelesaiannya.

\section{DAFTAR PUSTAKA}

Adikara, Fransiskus. 2013. Implementasi tata kelola teknologi informasi perguruan tinggi berdasarkan COBIT 5 pada laboratorium rekayasa perangkat lunak universitas esa unggul. Seminar Nasional Sistem Informasi Indonesia, $2-4$ Desember.

Alberch, Bob \& Pirani, Judith A. 2004. Using an IT governance structure to archieve alignment at the niversity of Cincinnati.

Andersen, Kim Viborg \& Danziger, James N. 1995. Information technology and the political world: The impacts of IT on capabilities interactions, orientations and values. International Journal of Public Administration Vol 18, 11, 1693-17244.

Aswati, Safrian., Mulyani, Neni., Siagian, Yessica. \& Syah, Arridha Zikra. Peranan 
Irwan "Evaluasi Pengelolaan Layanan Teknologi Informasi Menggunakan Framework COBIT 5:

Studi Kasus pada Institut Ilmu Sosial dan Ilmu Politik - IISIP YAPIS Biak”

sistem informasi dalam perguruan tinggi. Jurnal Teknologi dan Sistem Informasi, Vol 1, 2, Maret 2015, 79-86.

Evaluasi Diri Institut Ilmu Sosial dan Ilmu Politik (IISIP) YAPIS Biak, 2012.

Guritno, Suryo., Sudaryono. \& Rahardja, Untung. 2011. Theory and application of IT research: Metode penelitian teknologi informasi. ANDI.

Hardy, Gary. 2006. Using IT governance and COBIT to deliver value with IT and respond to legal, regulatory and compliance challenges. Information Security Technical Report II. Elsevier.

ISACA. 2012. COBIT5: A business framework for the governance and management of enterprise IT. USA.

ISACA. 2012. COBIT5: Enabling processes. USA.

ISACA. 2012. COBIT5: Module 5 the process capability assessment model, The COBIT5 foundation course. USA.

ISACA. 2012. COBIT5: Self-assessment guide, Using COBIT 5. USA

ITGI. 2013. Board Briefing on IT Governance 2nd Edition. IT Governance Institute.

Jogiyanto, H.M. \& Abdillah, Willy. 2011. Sistem tata kelola teknologi informasi. ANDI.

Maria, Evi., Fibriani, Charitas. \& Sinatra, Lina. 2012. The measurement of information technology performance in indonesian higher education institutions in the context of achieving institution business goals using COBIT framework version 4.1 (Case study: Satya Wacana Christian University, Salatiga). International Refereed Research Journal Vol-III, 3, July 2012, 9-19.

Moleong, Lexy J. 2007. Metodologi Penelitian Kualitatif. PT Remaja Rosdakarya Offset.
Noorhasanah., Winarno, Wing Wahyu. \& Adhipta, Dani. 2015. Evaluasi tata kelola teknologi informasi berbasis framework COBIT 5. Seminar Nasional Teknologi Informasi dan Multimedia. Yogyakarta 6 -8 Februari.

Nuraeni and Y. Bandung. 2012. Pengukuran kematangan tata kelola teknologi informasi untuk proses pengelolaan layanan gangguan TI menggunakan COBIT. Konferensi Teknologi Informasi dan Komunikasi untuk Indonesia.

Purwanto. 2010. Evaluasi tata kelola teknologi informasi menggunakan kerangka kerja COBIT dalam mendukung layanan sistem informasi akademik studi kasus: Universitas Budi Luhur. Jurnal Telematika AMKOM Vol. 2, 1

Putra, I Gusti Lanang Agung Raditya., Sinaga, Benyamin Langgu. \& Wisnubhadra, Irya. Evaluasi tata kelola sistem informasi akademik berbasis COBIT 5 di Universitas Pendidikan Ganesha. Jurnal Buana Informatika, Vol 6, 4, Oktober 2015, 279-288.

Rencana Strategis Institut Ilmu Sosial dan Ilmu Politik (IISIP) YAPIS Biak, 2012.

Ribeiro, Jorge. \& Gomes, Rui. 2009. IT governance using COBIT implemented in a high public educational institut - A Case Study.

Satria, Dhimas. 2010. Analisis level of maturity pengelolaan dan kepuasan end user terhadap tingkat layanan yang diberikan terkait kebijakan ugos (UGM goes open source) menggunakan COBIT framework. Universitas Gadjah Mada

Setiawan, Alexander. 2008. Evaluasi penerapan teknologi informasi di perguruan tinggi swasta Yogyakarta dengan menggunakan COBIT framework. Universitas Gadjah Mada. 
Setiawan, Alexander. 2010. Pengaruh kematangan, kinerja dan perkembangan teknologi informasi di perguruan tinggi swasta Yogyakarta dengan model COBIT framework. Seminar Nasional Informatika (SemnasIF) Yogyakarta, Mei 2010.

Sugiyono. 2012. Memahami Penelitan Kualitatif. Bandung. Alfabeta.

Wardani, Setia. \& Puspitasari, Mita. 2014. Audit tata kelola teknologi informasi menggunakan framework COBIT dengan model maturity level (studi kasus fakultas abc). Jurnal Teknologi, Vol 7, 1, Juni 2014.

Weill, Peter. \& Ross, Jeanne W. 2004. IT governance - how top performers manage IT decision rights for superior results. Harvard Business School Press 